\title{
IDENTIFICATION OF HUMAN DNA IN MIXTURE OF HUMAN AND CHICKEN BLOOD USING PCR WITH SPECIFIC PRIMER OF CYTOCHROME B GENE
}

\author{
Wimbuh Tri Widodo ${ }^{1}$, Ahmad Yudianto ${ }^{2}$, Sri Puji Astuti Wahyuningsih ${ }^{3}$ \\ ${ }^{1}$ Master of Forensic Science, ${ }^{2}$ Department of Forensic Medicine and Medicolegal, Faculty of Medicine, ${ }^{3}$ Department of \\ Biology, Faculty of Science and Technology, Universitas Airlangga, Surabaya, Indonesia
}

\section{ABSTRACT}

\begin{abstract}
This study aimed to identify human DNA from mixing human and chicken blood samples by utilizing Polymerase Chain Reaction $(P C R)$ and cytochrome $b$ gene primer. The cytochrome $b$ gene is a gene located in mitochondrial DNA and has high variation of sequence relation between one species and another. PCR analysis was performed using human cytochrome bene primer in variation of DNA templates (0 $\mathrm{ng}, 0.01 \mathrm{ng}, 0.1 \mathrm{ng}, 1 \mathrm{ng}, 10 \mathrm{ng}$ and $100 \mathrm{ng}$ ), human blood percentages $(100 \%, 50 \%, 40 \%, 25 \%, 10 \%$, $5 \%, 1 \%, 0 \%)$ and sample age before analysis (0 day, 3 days, 7 days, 10 days, and 15 days). The minimum DNA template obtained in this study was $0.01 \mathrm{ng}$ and minimum percentage of human blood in the mixture was 1\%. Blood spots on cloth isolated on days 0 , 3, 7, 10 and 15 could still be analyzed and the resulting of DNA band (157 bp) had the same intensity/thickness. From the results of this study, it can be concluded that human blood in the mixture of human and chicken blood can be identified using PCR with specific primers of cytochrome $b$ gene. PCR using specific primer of cytochrome b gene may help forensic practitioners to identify human sample in mixed biological samples.
\end{abstract}

Keywords: Identification of mixed biological samples; PCR; DNA; cytochrome b; forensic genes

\section{ABSTRAK}

Penelitian ini bertujuan untuk mengidentifikasi DNA manusia dari pencampuran sampel darah manusia dan ayam dengan memanfaatkan Polymerase Chain Reaction (PCR) dan gen sitokrom b primer. Gen sitokrom b adalah gen yang terletak pada DNA mitokondria dan memiliki variasi urutan hubungan yang tinggi antara satu spesies dengan spesies lainnya. Analisis PCR dilakukan menggunakan berbagai templat DNA (0 ng, 0,01 ng, 0,1 ng, $1 \mathrm{ng}, 10 \mathrm{ng}$ dan $100 \mathrm{ng})$, variasi persentase darah manusia (100\%, 50\%, $40 \% 25 \%, 10 \%, 5 \%, 1 \%, 0 \%)$ dan variasi panjang sampel sebelum analisis (0 hari, 3 hari, 7 hari, 10 hari, dan 15). Kerangka DNA minimum yang diperoleh dalam penelitian ini adalah 0,01 $\mathrm{ng}$ dan persentase minimum darah manusia dalam campuran $1 \%$. Titik darah pada kain yang diisolasi pada hari ke 0, 3, 7, 10 dan 15 masih dapat dianalisis dan pita DNA yang dihasilkan (157 bp) memiliki intensitas/ketebalan yang sama. PCR dengan primer spesifik gen sitokrom b membantu praktisi forensik untuk mengidentifikasi sampel asal manusia pada sampel pencampuran-sampel biologis.

Kata kunci: Identifikasi sampel biologis campuran; PCR; DNA; sitokrom b; gen forensik

Correspondence: Wimbuh Tri Widodo, Master of Forensic Science, Universitas Airlangga, Jl. Airlangga 4-6, Surabaya, Indonesia. Phone: +6285257251531. E-mail: wimbuhtriwidodo@gmail.com

pISSN:2355-8393 • eISSN: 2599-056x • doi: http://dx.doi.org/10.20473/fmi.v54i3.10009

- Fol Med Indones. 2018;54:184-188 • Received 12 Oct 2017 • Accepted 19 Apr 2018

- Open access under CC-BY-NC-SA license • Available at https://e-journal.unair.ac.id/FMI/

\section{INTRODUCTION}

Criminal acts may occur anywhere and at any time, including acts of murder or ill-treatment. The criminal acts also may occur near pets or farm animals so that the animal can be injured and even spraying blood. One of the most well-kept pets is chicken (Gallus gallus). Blood between humans and chickens has the same constituent components, so it is difficult to distinguish between human and chicken blood spots, especially if they have been mixed. Analysis to determine the sample of human or animal origin (chicken), or often referred to as species identification, can use methods based on immunological reactions (Bolin et al 1995), protein electrophoresis (Razin \& Rottem 1967) and protein isoelectric profiles (Skarpeid et al 1998). However, these methods still have many limitations and shortcomings, namely the need for a large number of samples, the target protein is easily degraded and damaged, and cross-reactions often occurs in species with close kinship.

Current species identification have used many DNA analysis methods. One of the methods uses cytochrome 
b gene and Polymerase Chain Reaction (PCR). The cytochrome $b$ gene has very limited variation in one species but varies greatly between one species and the other. Thus, it can be used for specific detection of certain species. The cytochrome $b$ gene is one of the genes located in mitochondrial DNA. The gene encodes the cytochrome protein $\mathrm{b}$ which is a structural protein in the mitochondria. The human cytochrome $b$ gene has length of $1140 \mathrm{bp}$ that lies in the order of bases to 14.747 to 15.887 in mitochondrial DNA. PCR is the amplification of desirable DNA fragments in vitro into millions and even billions of copies. The utilization of cytochrome $b$ genes using PCR with specific primers of cytochrome $b$ for the identification of mixed samples from various species has been widely practiced, such as by Kesmen et al (2007) who identified species in the mixture of pork, horse, and donkey meat that have been processed into sausages. The use of PCR with specific primers of cytochrome $b$ genes for the identification of mixed human and animal samples was also performed by Matsuda et al (2005), but in this study the sample had no variations in the mixing ratio.

Therefore, we performed a study on the identification of human DNA on the mixture between human and animal blood (chicken) in various comparisons using PCR with specific primers of human cytochrome $b$ gene. In this study, we also observed the minimum DNA concentrations and the age of blood spots that could still be detected using PCR with specific primers of the cytochrome gene $\mathrm{b}$.

\section{MATERIALS AND METHODS}

This study used primers designed by Matsuda et al (2005) and ordered from PT. Genetics Science Indonesia. The forward primer was 5'-TAGCAATAA TCCCCATCC TCCATATAT-3', and the reverse primer was 5'-ACTTGTCCAATGATGGTAAAAGG-3'. The sample used was human and chicken blood. Human blood was obtained by the Indonesian Red Cross (PMI). Chicken blood was taken from a chicken in a farm. The DNA of human blood, chicken blood and a mixture of human and chicken blood were extracted using the Wizard Genomic DNA Purification (Promega) by following the guidelines in the kit. DNA concentration was measured using a spectrophotometer based on absorbance at a wavelength of $260 \mathrm{~nm}$.

The isolated human DNA was diluted in concentrations of $100 \mathrm{ng}, 10 \mathrm{ng}, 0.1 \mathrm{ng}$, and $0.01 \mathrm{ng}$ (Kesmen et al 2007), then each was used for the template in PCR analysis with pre-denaturation program at $950 \mathrm{C}$ for 1 minute, denaturation at $95^{\circ} \mathrm{C}$ for $30 \mathrm{~s}$, annealing at $55^{\circ} \mathrm{C}$ for $30 \mathrm{~s}$, elongation at $72^{\circ} \mathrm{C}$ for $1 \mathrm{~min}$ and post-elong- ation at $72^{\circ} \mathrm{C}$ for $5 \mathrm{~min}$. PCR results were then stored in $4^{\circ} \mathrm{C}$ before electrophoresis. The electrophoresis results were seen in the UV illuminators and were documented for analysis.

The test was done by mixing human and chicken blood with human blood concentrations of $100 \%, 50 \%, 40 \%$, $25 \%, 10 \%, 5 \%, 1 \%$, and $0 \%$, respectively. Mixed blood was isolated for the DNA and was analyzed with PCR according to the procedure in the previous test. A total of $1 \mathrm{ml}$ of blood mixture was dropped on a cotton cloth for each treatment. Each droplet was left for 0, 3, 7, 10 and 15 days at room temperature. Then, the DNA was isolated and PCR was performed using specific primers of cytochrome $b$ gene. This test was also done to observe the difference of the intensity of the DNA bands produced on days $0,3,7,10$, and 15 .

\section{RESULTS}

\section{Minimum DNA template concentration}

Minimum DNA template concentrations in $0.01 \mathrm{ng}, 0.1$ $\mathrm{ng}, 1 \mathrm{ng}, 10 \mathrm{ng}$ and $100 \mathrm{ng}$ analyzed using PCR with human cytochrome $\mathrm{b}$ gene primer revealed the formation of DNA band in $2 \%$ in agarose gel, but in the concentration of $0.01 \mathrm{ng}$ the formed DNA band had looked thin (Fig. 1).

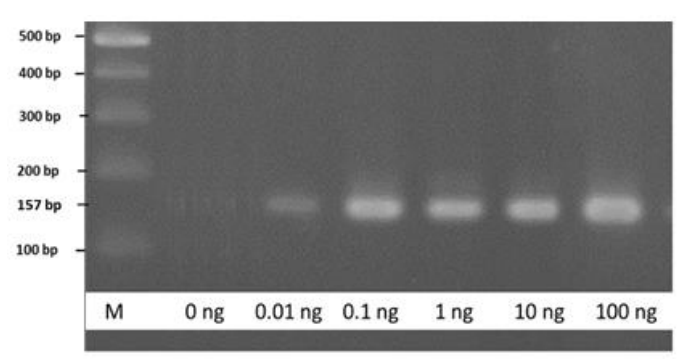

Fig. 1. Minimum DNA template concentration in $2 \%$ agarose gel; M: marker, $0 \mathrm{ng}, 0.01 \mathrm{ng}, 0.1 \mathrm{ng}, 1$ ng, $10 \mathrm{ng}$, and $100 \mathrm{ng}$ : DNA template concentration. A thick DNA band of $157 \mathrm{bp}$ was obtained in a sample with a template DNA concentrations of $0.1 \mathrm{ng}, 1 \mathrm{ng}, 10 \mathrm{ng}$, and $100 \mathrm{ng}$, but a thin DNA band is seen on a sample with $0.01 \mathrm{ng}$ DNA template concentration.

\section{Minimum percentage of human blood}

PCR analysis using human cytochrome $b$ gene specific primer revealed the formation of DNA band (157 bp) in $2 \%$ agarose gel in $10 \%, 25 \%, 40 \%, 50 \%$, and $100 \%$ human blood in the mixture of human and chicken blood. Whereas, in 5\% and $0 \%$ of human blood sample the DNA band was not visible (Fig. 2). PCR analysis 
was performed for 30 cycles in a DNA template of 100 ng. When the DNA template concentration was increased to $1000 \mathrm{ng}$ with 40 PCR cycles, the mixture of the sample with $1 \%$ and $5 \%$ human blood showed the presence of DNA band. The DNA bands produced in sample with $1 \%$ human blood were very thin (Fig. 3).

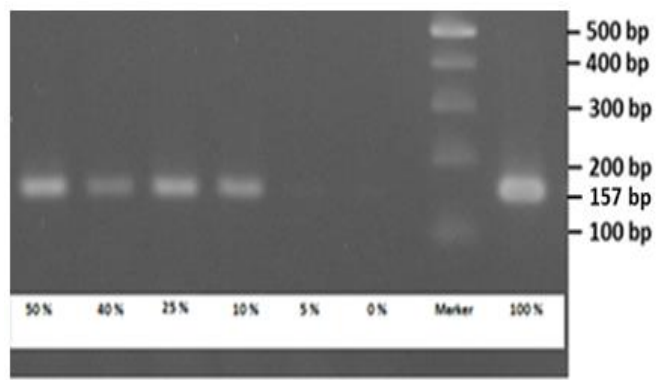

Fig. 2. Minimum percentage of human blood with DNA template of $100 \mathrm{ng}$ in $2 \%$ agarose gel; $\mathrm{M}$ : marker; $50 \%, 40 \%, 25 \%, 10 \%, 5 \%, 0 \%, 100 \%$ : human blood percentages. DNA band in $157 \mathrm{bp}$ is found in human blood samples of $100 \%, 50 \%$, $40 \%, 25 \%$, and $10 \%$. However, DNA band is not visible in human blood samples of $5 \%$ and $0 \%$.

\section{Spots on cloth and length of time}

PCR analysis in 40 cycles to the cotton cloth spotted with $10 \%$ human blood in mixed blood and DNA template of $0.1 \mathrm{ng}$ on days $0,3,7,10$ and 15 showed the formation of DNA band (157 bp) in $2 \%$ agarose gel (Fig. 4).

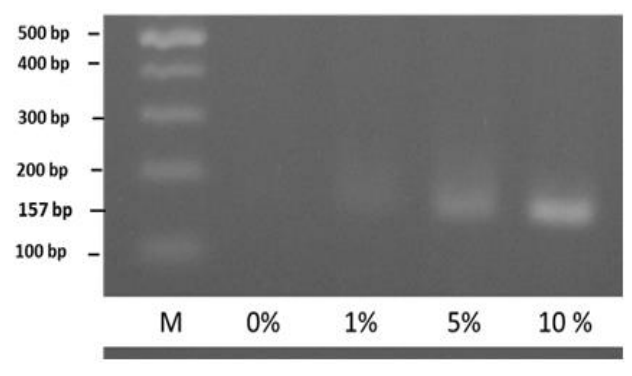

Fig. 3. Minimum percentage of human blood with DNA template of $1000 \mathrm{ng}$ in $2 \%$ agarose gel; M: marker; 0\%, 1\%, 5\%, 10\%: human blood percentages. DNA band in $157 \mathrm{bp}$ is found in human blood samples of $10 \%, 5 \%$, and $10 \%$. However, the DNA bands produced in samples with a human blood percentage of $1 \%$ are very thin.

\section{DISCUSSION}

\section{Minimum DNA template concentration}

In this study, $0.01 \mathrm{ng}$ DNA templates had been used for PCR analysis using human cytochrome $b$ gene primer, and the DNA band obtained was $157 \mathrm{bp}$. This result was in accordance with the primer measurement designed by Matsuda et al (2005) which was created to multiply the fragments of human cytochrome b gene from 902 base to 1058 base. The minimum amount of DNA templates in the PCR process depends on various factors, including the location of the desired target DNA, the reagents used and the suitability of the primary sequence with the target DNA sequence.

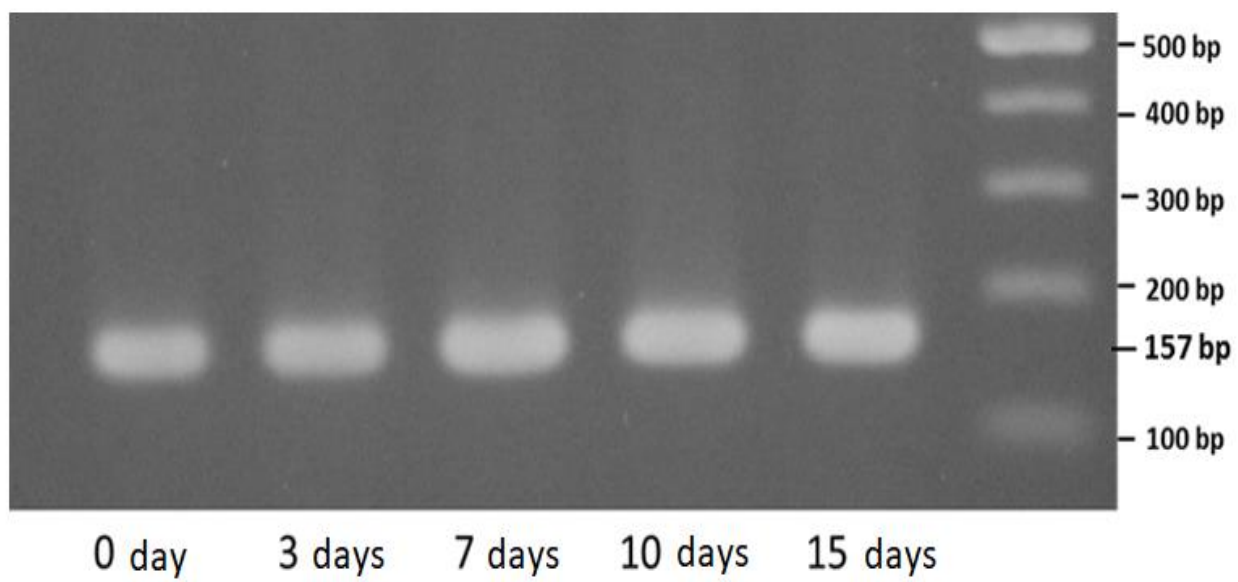

Fig. 4. The test on blood spot and the length of time in 2\% agarose gel. M: marker, 0 day, 3 days, 7 days, 10 days, and 15 days: human blood percentage. DNA bands in 157 bp are visible in all samples and no difference is found in the intensity/thickness of the DNA bands in all samples. 
The location of the cytochrome $\mathrm{b}$ gene in mitochondrial DNA provides many advantages. Mitochondrial DNA has high number of copies. Each cell can have hundreds of mitochondria and each mitochondria has 4-5 copies of mitochondrial DNA. Thus, one cell can have thousands of copies of mitochondrial DNA, as in the ovum, but on average it is estimated there are about 500 copies of mitochondrial DNA in each cell. The success of mitochondrial DNA isolation is higher than that of nuclear DNA isolation. Isolation of mitochondrial DNA can also be performed on biologically damaged samples. In such conditions, it is not possible to do nuclear DNA analysis because nuclear DNA has been degraded by environmental factors (Butler 2012).

\section{Minimum percentage of human blood}

In this study, $1 \%$ of human blood in mixed human and chicken blood yielded only thin DNA bands. Whereas, another study conducted by Shabani et al (2015) was able to detect $0.1 \%$ of pork gelatin from mixed gelatin of beef and pork. Gelatin-based capsules mixed with $0.1 \%$ pork gelatin can also be detected by Nikzad et al (2017). The thin ribbon is due to human blood (mammals) in which DNA only comes from white blood cells, whereas in chickens (non mammals) all blood cells have DNA (Alberts 2015).

The absence of mitochondria in red blood cells and platelets causes the amount of target DNA, that is mitochondrial DNA of human origin in a mixture of human and chicken blood, to be very small. The white blood cells that are the only source of DNA from human blood are only $0.1 \%$ of the total blood cell (Alberts 2015). Thus, although the total DNA obtained from the mixture of human and chicken blood is high, almost all of the total DNA is obtained from chicken blood.

The addition of DNA template concentration and PCR cycle had made samples with $5 \%$ and $1 \%$ human blood revealin DNA band. The addition of DNA template concentration and the number of PCR cycle reaction will increase DNA copy exponentially to an optimum point. However, once it has reached the optimum point, the addition of the cycle will not increase the number of copies of the resulting DNA. The optimum point ranges from 30-40 cycles (Grunenwald 2003).

Any repetition of the PCR cycle will reduce the effectiveness of DNA polymerase, denaturation efficiency and annealing efficiency due to increased template competence, so that the addition of PCR cycle above the optimum point will not increase the amount of produced PCR product. Increasing the number of DNA template of a PCR reaction will also increase the number of resulting DNA copy. However, if it is too many, the
DNA template will be visible on the agarose gel and create a background that covers the desirable DNA band. In addition, the use of too high DNA template concentrations will inhibit the running of PCR reactions (Grunenwald 2003).

\section{Spot test on the cloth and length of time}

Test results on days $0,3,7,10$ and 15 showed that the formation of thick DNA bands and the thickness intensity were almost the same. The appearance of DNA bands in all of these samples showed that up to 15 days of human and chicken blood mixtures can still be analyzed using PCR with human cytochrome $b$ gene. The intensity of the resulting DNA band is also very thick and clear when compared with the test results of at least a percent of blood mixture. It is suspected that it was also influenced by the cotton material of the cloth used. Cotton has strong properties. In wet conditions its strength increases by $25 \%$. It can absorb water (hygroscopic), resisting high heat from irons, and bleaching (Ernawati 2008). These properties cause DNA-containing blood cells to be absorbed in cotton so as to reduce the occurrence of DNA degradation, resulting in better PCR results.

The absence of differences in the intensity of the DNA bands produced from day 0 to day 15 was because blood conditions between day 0 to day 15 did not undergo much change. Once dripped on the cloth, the blood mixture will dry out. The dry conditions cause the work of deoxyribonuclease enzymes (DNAs) present in each cell to be inhibited so that the mixture of blood dripped on the cotton will last longer, and the DNA contained in the cell is difficult to degrade (Campbell \& Farrell 2014).

\section{CONCLUSION}

The identification of human DNA from a mixture of human and chicken blood was successfully performed with PCR using a specific primer of human cytochrome b gene with a minimum DNA template obtained of 0.01 ng. The minimal percentage of blood in the mixture of human and chicken blood was $1 \%$. DNA of human origin was also identified from the blotch of human and chicken blood on cotton and no difference in the intensity of the DNA bands was produced between day 0 and day 15 .

\section{REFERENCES}

Alberts B (2015). Molecular biology of the cell, 6th edition, Biochemistry and Molecular Biology Education. doi: 10.1002/bmb.20192. 
Bolin I, Lonroth H, Svennerholm AM (1995). Identification of Helicobacter pylori by immunological dot blot method based on reaction of a species-specific monoclonal antibody with a surface- exposed protein. Journal of Clinical Microbiology 33, 381-384

Butler JM (2012). Advanced topics in forensic DNA typing: Methodology. Academic Press. doi: 10.1111/j. 1556-4029.2012.02199.x.

Campbell MK, Farrell S (2014) Biochemistry. 8th ed. Biochemistry textbook

Ernawati (2008). Tata Busana Jilid 1. Jakarta, Direktorat Pembinaan Sekolah Menengah Kejuruan

Grunenwald H (2003). Optimization of polymerase chain reactions. Methods in Molecular Biology-PCR Protocols 226, 89-99. doi: 10.1385/1-59259-384-4:89

Kesmen Z, Sahin F, Yetim H (2007). PCR assay for the identification of animal species in cooked sausages. Meat Science 77, 649-653. doi: 10.1016/j.meatsci. 2007.05.018

MatsudaH, et al (2005). Identification of DNA of human origin based on amplification of humanspecific mitochondrial cytochrome b region. Forensic
Science International 152, 109-114. doi: 10.1016/j. forsciint.2004.07.019

Nikzad J, et al (2017). Simultaneous detection of bovine and porcine DNA in pharmaceutical gelatin capsules by duplex PCR assay for Halal authentication. DARU Journal of Pharmaceutical Sciences 25, 3. doi: 10.118 6s40199-017-0171-3

Rahman MM, et al (2014). Polymerase chain reaction assay targeting cytochrome $\mathrm{b}$ gene for the detection of dog meat adulteration in meatball formulation. Meat Science 97, 404-409. doi: 10.1016/j.meatsci.2014. 03. 011

Razin S, Rottem S (1967). Identification of mycoplasma and other microorganisms by polyacrylamide-gel electrophoresis of cell proteins. Journal of Bacteriology 94, 1807-1810

Skarpeid HJ, Kvaal K, Hildrum KI (1998). Identification of animal species in ground meat mixtures by multivariate analysis of isoelectric focusing protein profiles. Electrophoresis 19, 3103-3109. doi: 10.1002/ elps. 1150191811 